\title{
RESTAURANTS AND HOTELS \\ EXPENDITURE IN POLISH HOUSEHOLDS OF THE ELDERLY
}

\author{
MARLENA PIEKUT
}

\begin{abstract}
A B S T R A C T
The age of household members is an important factor for expenditures. The aim of the study is to investigate the level of expenditure on restaurants and hotels incurred in Polish households of the elderly in 2004-2013 and to identify the factors affecting such expenditures. The source of information used in the study was the household budget survey of the Central Statistical Office of Poland. The main methods used in this study were variance analysis and regression analysis. Restaurants and hotels expenditure increases every year together with their share in total household expenditure. The most important factors affecting the restaurants and hotels spending in Polish households of the elderly are: income per capita and the level of education of the head of the family. The study on consumption determinants at different groups leads to better understanding of consumer behavior circumstances and thereby ensuring a good quality of life for the people of the elderly.
\end{abstract}

KEY WORDS

household of the elderly, expenditure on restaurants and hotels, factors spending

DOI: 10.1515/emj-2016-0009

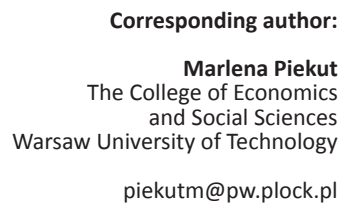

\section{INTRODUCTION}

Socio-economic development and enrichment of societies are directly connected with an increased interest in services associated with restaurants and hotels.

The increase of expenditure on catering and accommodation is observed with each passing year. In some groups they increase faster in the other more slowly. Differences in spending are observed among consumers of different ages. Age of consumers is not the only factor determining these expenditures. Consumers in the same age do not have the same patterns of consumption, because these expenses are related to the education of consumers, their income, location of household and other factors.

The aim of the study was to investigate the level of expenditure on restaurants and hotels incurred in
Polish households in 2004-2013 and to identify the factors affecting such expenditures. The aim was also to compare the level and the structure of expenditures on restaurants and hotels in Polish households distinguished by income and socioeconomic group, education level and gender taking into account the head of the family.

\section{LITERATURE OVERVIEW}

The process of satisfying needs occurs through household. Using the restaurants and hotels are a category higher-order needs (Maslow's hierarchy). As a percentage of total household spending, food expenditure continues to shrink because of increased 
income, while the share of services has been increasing. The food consumption trend has been shifting towards food away from home (Mancino et al., 2009; Liu et al., 2013). The growing interest in catering services among consumers is observed in many countries, for example in the United States (Mancino et al., 2009), in Canada (Jensen \& Yen, 1996), in Taiwan (Chang \& Yen, 2010), in Spain (Mutlu \& Gracia, 2006; Angulo et al., 2007), in Greece (Mihalpoulos \& Demoussis, 2001), in Italy (Montini, 2001), in Asian (Pingali, 2006; Bai et al., 2012). Changes in food consumption behaviours related to food away from home are driven by a wide range of factors including geography, demography, disposable income, urbanization, infrastructure, globalization, marketing, religion, culture, women participation in labor force, education, tourism, and consumer attitudes (Bozoglu et al., 2013). These changes have contributed to increases importance of catering services.

Accommodation services often combine with tourist trips. Shares of people taking part in tourist trips is still growing (Turystyczne..., 2015). There are also increasing interests in tourism among seniors (Sawińska, 2014; Badora, 2015).

The larger household expenditure on restaurants and hotels could have a positive impact on economic growth. Expenditure on restaurants and hotels generates income of enterprises, increases the sales of goods and services and has a positive impact on the labour market, as well as on trade balance and public revenues (Piekut \& Kludacz, 2014). Therefore it is essential to analyse expenditure in different types of households. Both the level and structure of household consumption depend on cooperative action of several factors (Gutkowska et al., 2012). Identification, features of households that combine to the expenditure on restaurants and hotels, can contribute to a better understanding of consumers on the market for those services.

The survey findings show (Kowalczuk, 2013) that the specificity of expectations of different groups households should be taken into consideration while drawing up the catering outlets' marketing strategies in order to fully meet the needs of those groups of consumers and stimulation to their activity as regards purchasing behaviour.

An age of consumer is an important determinant in the variation of consumption (Bylok, 2013). The growth of the number of senior consumers as well as their increasing purchasing abilities (what is indicated, inter alia, by growing incomes) affect the change of perception of this group of consumers among offerers in the market (Olejniczak, 2015). With the aim of presenting the specifics of the category of elderly consumers, the results of personal research on the consumer behavior of elderly consumers on the market of services associated with catering and accomodation will be indicated. Economic, social and individual factors determining the consumer behavior of elderly people will be identified.

\section{RESEARCH METHODS}

The research material was obtained from individual unpublished data of the household budget survey conducted by the Central Statistical Office of Poland in 2012. The collection included more than 37 thousand households.

This study reviews the households which head were as old as 60 or older, approximately $32,1 \%$ of total number of households.

A head of household is defined as the person who gets highest wage \& salary income of all household members.

The data was obtained from the research project "Analysis of the consumption level in households, with particular consideration of the differences between voivodeships".

The study considered correlation relationships to examine the link between the level of household expenditures and restaurants and hotels consumption. The households were divided into groups taking into account education of the head of the household, the level of disposable income per person, socioeconomic group membership and gender of the head of the household. The construction of correlation relations based on equality of variance, these are the measures of dimensionless quantities which amount to values between 0 and 1 . When variables are uncorrelated, the measures are equal to 0 ; when there are any functional dependence between variables the coefficient value is between the range mentioned above. The stronger the correlation the closer to 1 the coefficient value.

The analysis of variance was used for testing the significance of differences between arithmetic means of many groups. To explore the significance of differences between pairs of variables the Scheffe test was applied. It is particularly useful in analysis of variance. It is one of the tests examining statistical 
significance which carries out a comparison of posthoc. This is the most conservative test. Therefore the application of this test results in the fewer significant differences between averages (Wątroba, 2004). The analyzed data was weighted.

Multiple regression analysis was used to study the characteristics of households determining the restaurants and hotels expenditure. The overall objective of the multiple regression analysis is to the economic crisis in the years 2008-2009 the proportion of expenditure on restaurants and hotels in the structure of household budgets has stabilized, but then they started to increase (Fig. 1).

Restaurants and hotels expenditure depends on many determinants. One of them is the age of family members.

The value of the correlation coefficient between restaurants and hotels expenditure and the age of the

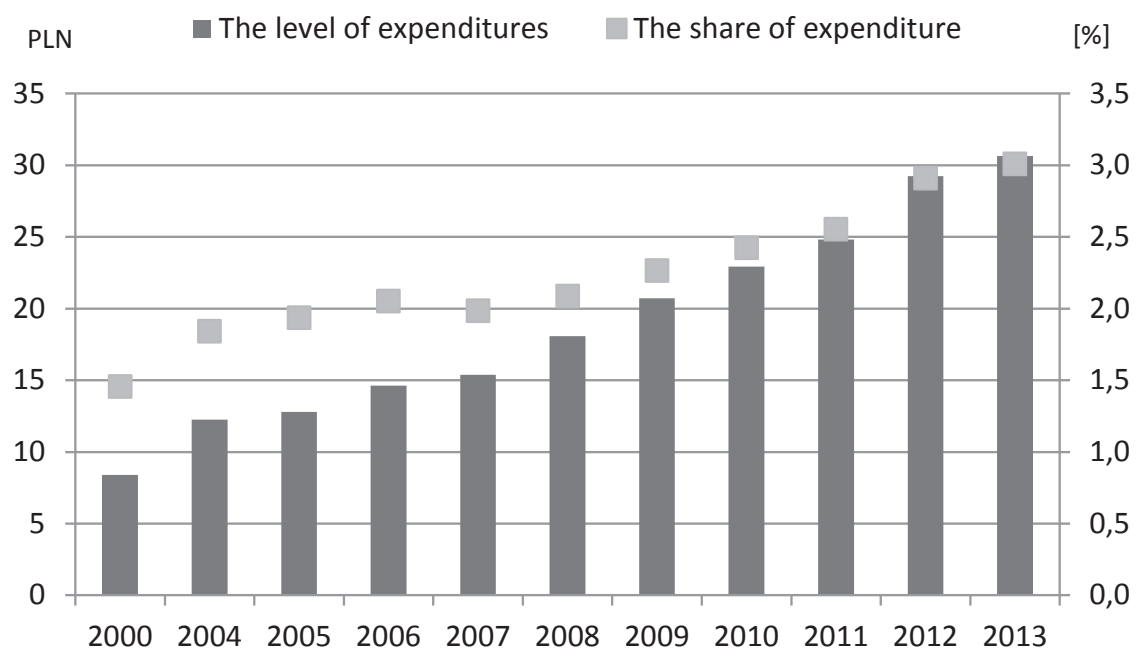

Fig. 1. Restaurants and hotels expenditure per capita in PLN (left scale) and their share (right scale) in total expenditure of Polish households in the years 2000-2013

Source: own work based on data from Central Statistical Office.

investigate relationship between several independent variables and the dependent variable. The final model shows the „optimal” set of independent variables, assuming that construction of the model was successful, no potential variable was omitted, and the data is properly interpreted (Kleinbaum et al., 2013; Wątroba, 2008).

\section{RESTAURANTS AND HOTELS EXPENDITURE IN BUDGETS OF POLISH HOUSEHOLDS}

Data from the Household Budget Survey indicate that the average monthly expenditure on restaurants and hotels per capita for the period 2000-2013 increased 3.6-fold, from almost 8 PLN in 2000 to almost 31 PLN in 2013. The share of restaurants and hotels spending in the total expenditure of households amounted to $1.5 \%$ in 2000 and $3.0 \%$ in 2013. During household head was 0.104 .

Restaurants and hotels expenditure in household with a head aged 70 and older were more than 0.6fold lower than for all households and 2.6 - fold lower than in households whose head was under 30 years old (Tab. 1). The average monthly expenditure on restaurants and hotels in households which head was the youngest reached about 47 PLN per person, while in the households whose head was between 60 and 70 years - about 20 PLN per person, and over 70 years old - 18 PLN per person. In the age group of 70 and over, expenditures on restaurants and hotels were higher than in young people households.

Shares of restaurants and hotels expenditure in the total household expenditure have ranged from $1.7 \%$ in the age group of 60 and over to $4.5 \%$ in the age group of 30 and under. 
Tab. 1. The level of restaurants and hotels expenditure and the share of expenditure in the total expenditure in Polish households due to the age of the household head in 2012

\begin{tabular}{|l|c|c|}
\hline $\begin{array}{c}\text { THE AGE OF THE HOUSEHOLD } \\
\text { HEAD }\end{array}$ & $\begin{array}{c}\text { RESTAURANTS AND HOTELS } \\
\text { EXPENDITURE PER CAPITA }\end{array}$ & $\begin{array}{c}\text { THE SHARE OF EXPENDITURE } \\
\text { IN THE TOTAL EXPENDITURE }\end{array}$ \\
\hline for all households & 29.35 & 2.9 \\
\hline Less than 30 years old & 46.63 & 4.5 \\
\hline $30-39$ & 40.39 & 4.2 \\
\hline $40-49$ & 25.99 & 2.8 \\
\hline $50-59$ & 22.83 & 2.2 \\
\hline $60-70$ & 19.90 & 1.7 \\
\hline More than 70 years old & 18.06 & 1.7 \\
\hline
\end{tabular}

Source: own work based on data from Central Statistical Office.

\section{THE LEVEL AND SHARE OF} EXPENDITURES ON RESTAURANTS AND HOTELS IN DIFFERENT POLISH HOUSEHOLD TYPES OF THE ELDERLY

\subsection{EDUCATION OF HOUSEHOLD HEAD AND EXPENDITURE ON RESTAURANTS AND HOTELS}

Restaurants and hotels expenditure was different depending on the education of household head. In order to identify significant differences in expenditures on restaurants and hotels between households of different types, the Scheffe test was applied. The analysis didn't reveal any statistically significant differences $(p<0,05)$ in expenditure on restaurants and hotels among households headed by people with primary and basic vocational education. According to Scheffe test, among the other households, the significant differences in the level of such expenses were revealed (Tab. 2).
The correlation coefficient between the level of expenditures and households divided according to education level of the head of the household was 0,134 .

Analysis of the level of expenditures on restaurants and hotels, has led to the following conclusions. With the increase of the level of education, the level of expenditures on previously mentioned products and services increase. In low educated groups the share of expenditures on restaurants and hotels was equal to $1.3-1.4 \%$; in households of higher educated people those expenses amounted 2.5\% (Fig. 2).

\subsection{DISPOSABLE INCOME PER CAPITA AND EXPENDITURE ON RESTAURANTS AND HOTELS}

The level of income per one household member is a key factor in determining consumption.

According to Scheffe test, it was proved that there were statistically significant $(\mathrm{p}<0.005)$ differences between all groups of households distinguished by

Tab. 2. Significant $(p<0,05)$ and insignificant differences in expenditures on restaurant and hotels among households of the elderly led by people with different levels of education

\begin{tabular}{|l|c|c|c|c|}
\hline EDUCATION OF HOUSEHOLD HEAD & $\begin{array}{c}\text { LOWER } \\
\text { SECONDARY, } \\
\text { PRIMARY OR LESS }\end{array}$ & $\begin{array}{c}\text { BASIC } \\
\text { VOCATIONAL } \\
\text { EDUCATION }\end{array}$ & $\begin{array}{c}\text { SECONDARY } \\
\text { AND POST- } \\
\text { SECONDARY } \\
\text { EDUCATION }\end{array}$ & $\begin{array}{c}\text { HIGHER } \\
\text { EDUCATION }\end{array}$ \\
\hline lower secondary, primary or less & 0,6596 & 0,6596 & 0,0000 & 0,0000 \\
\hline basic vocational education & 0,0000 & 0,0000 & 0,0000 & 0,0000 \\
\hline $\begin{array}{l}\text { secondary and post-secondary } \\
\text { education }\end{array}$ & 0,0000 & 0,0000 & 0,0000 & 0,0000 \\
\hline higher education & & & & \\
\hline
\end{tabular}

Source: own work based on data from Central Statistical Office. 


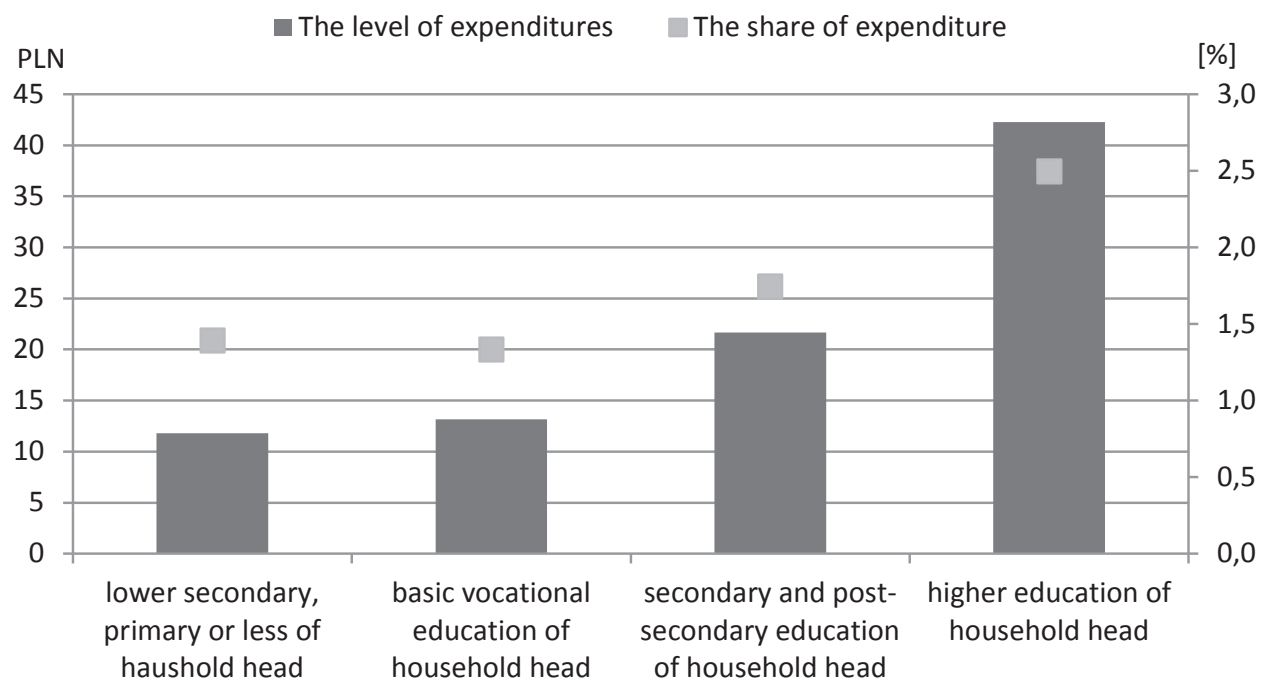

Fig. 2. The level (left scale) and share (right scale) of spending on restaurants and hotels Polish households of the erderly depending on the education of the head of the household

Source: own work based on data from Central Statistical Office.

the level of income per capita in households and expenditure on restaurants and hotels.

Coefficient relationship between the level of disposable income and restaurants and hotels expenditure in the households was 0,172.

Average monthly restaurants and hotels expenditure in households from the first income group was around 6 PLN per capita, and from the third income group - six times more, that is 37 PLN per capita. In households with more difficult material situation the share of expenditures on restaurants and hotels reached 1.0\%; in households with the largest

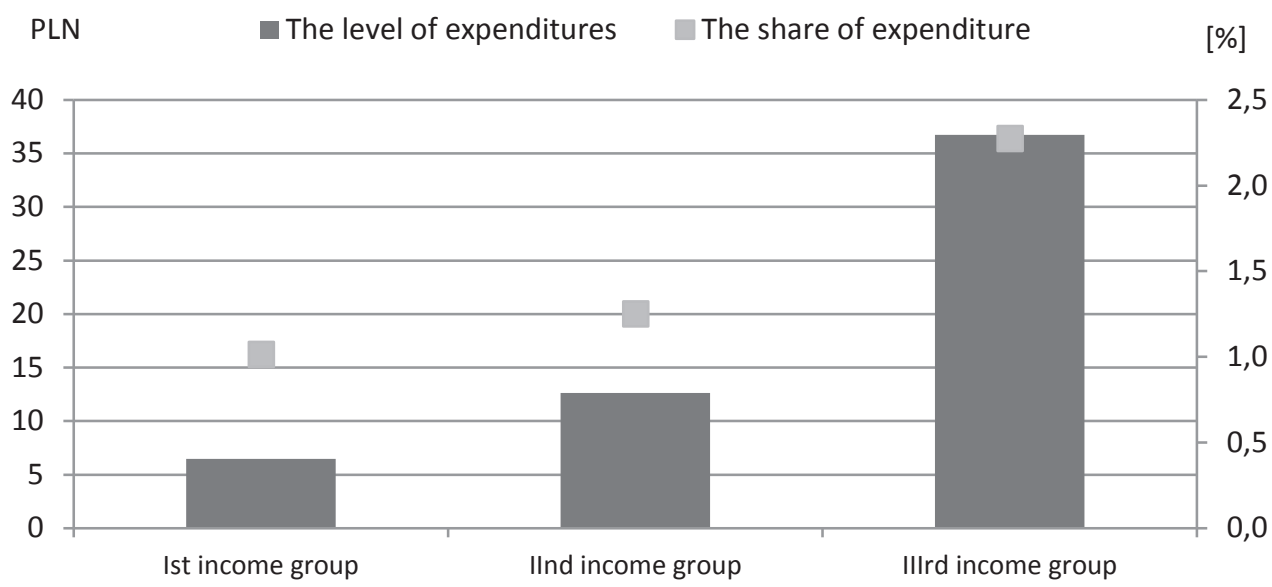

Fig. 3. The level (left scale) and share (right scale) of spending on restaurants and hotels Polish households of the erderly depending on the education of the head of the household

Source: own work based on data from Central Statistical Office. incomes per person those expenses amounted 2.3\% (Fig. 3).

\subsection{SOCIO-ECONOMIC GROUP OF HOUSEHOLD AND EXPENDITURE ON RESTAURANTS AND HOTELS}

The next analysis aimed to demonstrate the significance of differences between groups of households due to socioeconomic group membership. The research can be summerized as follows. There were no statistically significant differences in restaurants and hotels expenditures between 
households of blue-collar workers and white-collar workers, self-employed, and between of white-collar workers and retirees, pensioners, living on supplementary welfare allowance (details in the Tab. 3), there were statistically significant differences between the remaining households (test Scheffe).

The correlation coefficient between the level of expenditures and households distinguished according to socioeconomic group was 0,113 .
Houselolds of white collar workers and selfemployed had the highest level of expenditures (PLN 52 and 55 per capita). Households of farmers and blue-collar workers have spent the least on the aforementioned products and services - PLN 8 and PLN 14 per capita respectively (Fig. 4).

The largest share of spending was observed in households of self-employed (3.4\%), living on

Tab. 3. Significant $(p<0,05)$ and insignificant differences in expenditures on restaurant and hotels among households of the elderly depending on the socioeconomic group of the household

\begin{tabular}{|c|c|c|c|c|c|c|c|c|}
\hline $\begin{array}{c}\text { HOUSEHOLDS BY SOCIOECONOMIC } \\
\text { GROUPS }\end{array}$ & 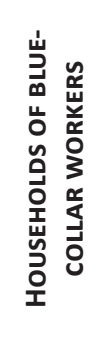 & 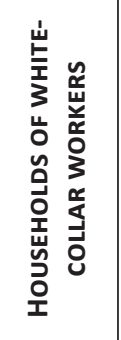 & 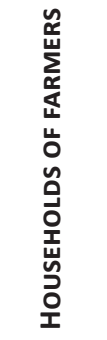 & 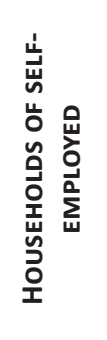 & 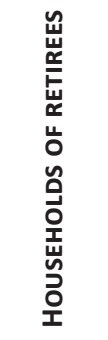 & 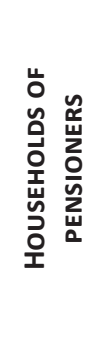 & 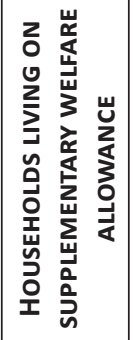 & 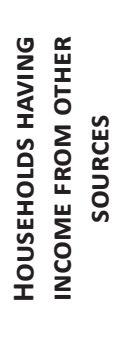 \\
\hline Households of blue-collar workers & & 0,0000 & 0,9439 & 0,0000 & 0,7746 & 0,9890 & 0,9933 & 0,0671 \\
\hline Households of white-collar workers & 0,0000 & & 0,0000 & 0,9986 & 0,0000 & 0,0000 & 0,0000 & 0,8671 \\
\hline Households of farmers & 0,9439 & 0,0000 & & 0,0000 & 0,2324 & 0,5506 & 0,7591 & 0,0149 \\
\hline Households of self-employed & 0,0000 & 0,9986 & 0,0000 & & 0,0000 & 0,0000 & 0,0000 & 0,7351 \\
\hline Households of retirees & 0,7746 & 0,0000 & 0,2324 & 0,0000 & & 0,9947 & 1,0000 & 0,1806 \\
\hline Households of pensioners & 0,9890 & 0,0000 & 0,5506 & 0,0000 & 0,9947 & & 1,0000 & 0,1334 \\
\hline $\begin{array}{l}\text { Households living on supplementary } \\
\text { welfare allowance }\end{array}$ & 0,9933 & 0,0000 & 0,7591 & 0,0000 & 1,0000 & 1,0000 & & 0,3619 \\
\hline $\begin{array}{l}\text { Households having income from } \\
\text { other sources }\end{array}$ & 0,0671 & 0,8671 & 0,0149 & 0,7351 & 0,1806 & 0,1334 & 0,3619 & \\
\hline
\end{tabular}

Source: own work based on data from Central Statistical Office.

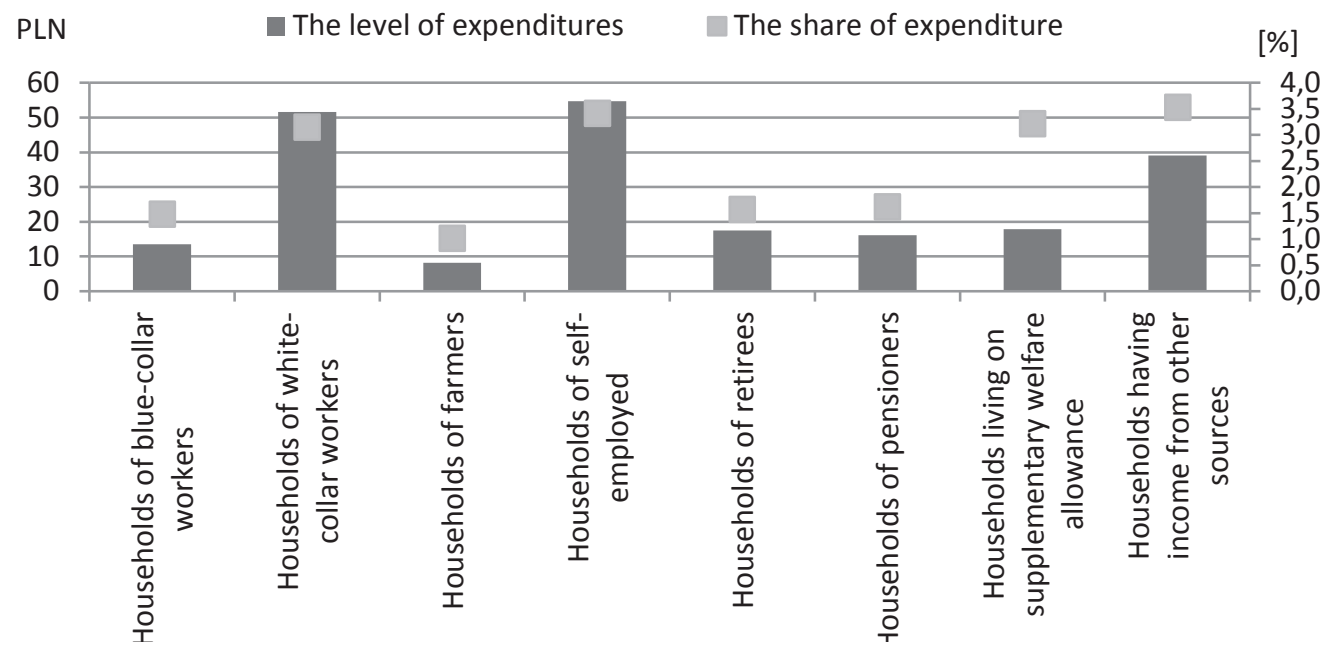

Fig. 4. The level (left scale) and share (right scale) of spending on restaurants and hotels Polish households of the erderly depending on the socioeconomic group of the household

Source: own work based on data from Central Statistical Office. 
supplementary welfare allowance (3.2\%) and of white-collar workers (3.1\%). The smallest share of expenditures were in households of farmers (1.0\%) and of retirees and pensioners (each with 1.6\%).

\subsection{GENDER HOUSEHOLD HEAD AND EXPENDITURE ON RESTAURANTS AND HOTELS}

The results showed no statistically significant differences in the level of expenditure on restaurants

Tab. 4. The results of regression analysis to estimate the impact of independent variables on restaurants and hotels expenditure in Polish households of the elderly in 2012 (statistically significant $p<0,05$ )

\begin{tabular}{|c|c|c|c|c|c|c|}
\hline SPECIFICATION & $\underset{⿱ ㇒}{\mathbb{E}}$ & 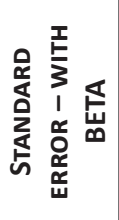 & 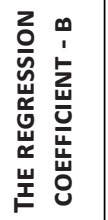 & 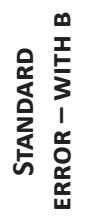 & $\underset{\substack{\infty \\
\stackrel{m}{m}}}{\stackrel{m}{r}}$ & உ \\
\hline Free term variable & & & 17,19 & 5,084 & 3,38 & 0,0007 \\
\hline Disposable income per capita & 0,221 & 0,0062 & 0,02 & 0,000 & 35,86 & 0,0000 \\
\hline $\begin{array}{l}\text { Household location: town with a } \\
\text { population exceeding } 500000\end{array}$ & 0,023 & 0,0082 & 5,24 & 1,853 & 2,83 & 0,0047 \\
\hline Households of retirees & $-0,091$ & 0,0181 & $-15,96$ & 3,193 & $-5,00$ & 0,0000 \\
\hline Number of people & $-0,045$ & 0,0069 & $-2,26$ & 0,343 & $-6,60$ & 0,0000 \\
\hline Households of self-employd & 0,009 & 0,0074 & 5,17 & 4,442 & 1,16 & 0,2443 \\
\hline Households of white-collar workers & $-0,006$ & 0,0100 & $-2,32$ & 3,739 & $-0,62$ & 0,5346 \\
\hline Marriages, single people, older, inactive & $-0,025$ & 0,0067 & $-3,77$ & 1,005 & $-3,75$ & 0,0002 \\
\hline Education of household head: higher & 0,020 & 0,0058 & 4,48 & 1,281 & 3,50 & 0,0005 \\
\hline Education of household head: primary & 0,021 & 0,0061 & 3,41 & 0,985 & 3,47 & 0,0005 \\
\hline Household location: village & $-0,058$ & 0,0106 & $-9,23$ & 1,673 & $-5,52$ & 0,0000 \\
\hline $\begin{array}{l}\text { Household location: town with a } \\
\text { population between } 20000 \text { and } 99000\end{array}$ & $-0,042$ & 0,0092 & $-7,71$ & 1,713 & $-4,50$ & 0,0000 \\
\hline $\begin{array}{l}\text { Household location: town with a } \\
\text { population between } 200000 \\
\text { and } 499000\end{array}$ & $-0,034$ & 0,0078 & $-8,11$ & 1,898 & $-4,27$ & 0,0000 \\
\hline $\begin{array}{l}\text { Household location: town with a } \\
\text { population less than } 20 \text { thousand } \\
\text { inhabitants }\end{array}$ & $-0,024$ & 0,0084 & $-5,12$ & 1,810 & $-2,83$ & 0,0047 \\
\hline Number of disabled people & $-0,013$ & 0,0056 & $-1,58$ & 0,664 & $-2,38$ & 0,0171 \\
\hline $\begin{array}{l}\text { Married couples with children of school } \\
\text { age }\end{array}$ & 0,011 & 0,0053 & 8,37 & 4,038 & 2,07 & 0,0381 \\
\hline $\begin{array}{l}\text { Married couples with children in } \\
\text { preschool }\end{array}$ & 0,011 & 0,0053 & 16,49 & 8,229 & 2,00 & 0,0450 \\
\hline Households of blue-collar workers & $-0,042$ & 0,0101 & $-15,19$ & 3,646 & $-4,16$ & 0,0000 \\
\hline Households of pensioners & $-0,054$ & 0,0136 & $-13,45$ & 3,374 & $-3,99$ & 0,0001 \\
\hline Households of farmers & $-0,025$ & 0,0077 & $-14,39$ & 4,340 & $-3,32$ & 0,0009 \\
\hline $\begin{array}{l}\text { Married couples with young people } \\
\text { educating themselves }\end{array}$ & 0,008 & 0,0057 & 2,34 & 1,680 & 1,40 & 0,1628 \\
\hline Age of the reference person & 0,006 & 0,0059 & 0,06 & 0,056 & 1,06 & 0,2886 \\
\hline
\end{tabular}

Source: own work based on data from Central Statistical Office. 
and hotels between households divided by gender of household head.

\section{DETERMINANTS \\ OF RESTAURANTS AND HOTELS EXPENDITURE}

In order to estimate the impact of household characteristics on restaurants and hotels expenditure, the regression analysis was performed.

To develop the model, it was necessary to enter the following independent variables: disposable income per capita, age of household head, household size, education of household head (no education, primary, basic vocational, secondary or post-secondary education), the number of disabled people in the household, location of the household (village, town with less than 20 thousand inhabitants, the town with a population between 20000 and 99000 , the town with a population between 200000 and 499000 , the town with a population exceeding 500 000), the family life cycle stage (married couples with children of preschool age; married couples with children of school age; older marriages (couples) without children - professionally active; older marriages (couples) without children - professionally inactive), socio-economic group of the household. The dependent variable was monthly expenditure on restaurants and hotels per person in the household.

Qualitative variables were transformed into dummy variables. When we estimated the models with systems of dummy variables, it was necessary to remove one of the dummy variable in each system, in order to avoid the collinearity.

The model created for restaurants and hotels expenditure in Polish households of the elderly turn out to be significant $(\mathrm{F} 21.34=134.02)$. All independent variables entered into the model explained $8 \%$ of the variance in the dependent variable $(\mathrm{R} 2=0.08)$. The standard error of estimation was 72.230 .

It has been shown that the most important characteristics that determine the restaurants and hotels expenditure were: disposable income per capita and location of household. The increase in disposable income by 1 PLN leads to increased in restaurants and hotels expenditures by 0.02 PLN. Restaurants and hotels expenditure in metropolitan households was statistically higher by nearly 5 PLN per household (Tab. 4).
Lower restaurants and hotels expenditure may be related to:

- the household of retirees (the restaurants and hotels expenditure in such households are lower by nearly 16 PLN);

- number of people (the presence of one more person in the household reduces the expenditure of 2.3 PLN);

- the households of marriages, single people, older, inactive (the restaurants and hotels expenditure in such households are lower by nearly 3.8 PLN).

\section{DISCUSSION OF RESULTS}

Poles spend more and more of household budgets on restaurants and hotels. Despite increased expenditure, in Polish households - next to Romanians, Bulgarians and Lithuanians - is observed the lowest levels and shares of expenditure on restaurants and hotels among European countries. Generally the North and West European countries have reached the higher level of restaurants and hotels expenditure compared to the East European countries. The households from the north-west Europe incur a higher consumption expenditure with their better structure at the same time, it means less spending on basic goods and more on services (Piekut, 2013, pp. 64-80). Whereas the households from East European countries allocate significant part of their budgets on their basic needs (food, home maintenance).

The larger restaurants and hotels expenditure the could have a positive impact on economic growth. Development of services generates income of enterprises, increases the sales of services and has a positive impact on the labour market, as well as on trade balance and public revenues.

In households with elderly was spent least for restaurants and hotels. The survey (Zalega, 2013, pp. 56-77) also shows that the households of the elderly, often reduce expenditure for financial reasons. In the study of Social Diagnosis (Czapiński \& Panek, 2014), the pensioners were one of the groups forced to resign from many services due to financial reasons.

The most important determinant of spending on restaurants and hotels were disposable incomes per person. The leading role of this factor is also highlighted in other studies (Laskowski, 2014; Piekut \& Gutkowska, 2015, pp. 527-530). In the research Social Diagnosis 2013 demonstrated that the greatest 
percentage of the people made to resignation from selected forms of participation in cultural levels was in the poorest households. Most of resignations from vacation trips happened in pensioners' households (Czapiński \& Panek, 2014). Household income specifies the standard of living, ability to satisfy the consumption needs, and consequently the quality of life (Rout, 2010, pp. 445-460; Siwuel et al., 2010, pp. 193-218). Sniadek (2007) indicates that in the USA and Western Europe increasing interest of tourism industry in servicing senior market results in a relatively high level of tourism consumption of this age group. Polish seniors, in contrast to their Western or American counterparts or other age groups indicate a low level of tourism consumption. The main reason for this situation is both a limited buying potential of Polish seniors as well as system of values held, where active ways of spending free time are relatively low in the rank.

Next to disposable income, important determinants of expenditure on restaurants and hotels in the households of the elderly were: the location of household, education of household head and socioeconomic group. It did not show statistically significant differences in expenditure on restaurants and hotels due to gender of the head of the household.

According to the study of the expenditure in Spanish households there are budget restrictions on services expenditure that are the result of low levels of income and other household characteristics both financial (ability to save money, the number of unemployed household members) and non-financial (education level of household members, their age and health status), (Alegre et al., 2010).

Other study indicates that (Erbe Healy, 2014, pp. 792-804) modern households within France, the UK and Ireland are spending a higher percentage on foods away from home with some households, specifically those with a head of household who is young, single and employed, spending, on average, two-thirds of their household food budget dining away from home.

The restaurants and hotels expenditures are partially connected with tourism. Rapoport and Rapaport (1975) and Lawson (1991, pp. 12-17) stated that age is the main factor of expenditure on tourism. Empirical studies show that high incomes positively influence decisions on traveling (Alegre et al., 2009, pp. 45-56; Eugenio-Martin \& Campos-Soria, 2011, pp. 2519-2531) and this effect is greater if the people have medium or high income (Fish \& Waggle, 1996, pp. 70-74; Nicolau \& Más, 2005, pp. 49-69).
As the society gets older, the structure of consumer spending changes. Therefore it is necessary to adjust supply of services and goods to elder people (Bąk, 2012) and it is noted that in future, seniors need will have to be respected to a greater extent. It is also pointed out that probably together with lengthening life, the range of age and behavior pattern typical for older people today will be shifted on the axis of life. Additionally, longer productive career will result in slowed marketing changes (Migdał-Najman \& Szreder, 2013, pp. 2-8). Piekut (2013) claims that improving financial situation and increasing life expectancy and also to improve the health of the elderly (Bernini \& Cracolici, 2015, pp. 191-205) will cause increasing free time and consumers will try to get the optimal management of time.

\section{CONCLUSIONS}

The carried analysis of restaurants and hotels spending in Polish households lead to some interesting findings and conclusions.

Restaurants and hotels expenditure has been rising every year. It has been also noticed an increasing share of such expenditure in total household expenditure. Current trends in consumer behavior and demographic changes will result in a further increase in restaurants and hotels expenditure in household budgets

The biggest relationship between restaurants and hotels expenditure and household characteristics was demonstrated in relation to the disposable income per capita and then the location of households. The higher disposable incomes per capita in household and household location in towns of 500000 people and more lead to higher restaurants and hotels spending.

The global trends in consumption and the widespread enrichment of societies empower to the conclusion that the share of restaurants and hotels expenditure will increase in the households and existing differences between households will gradually disappear. Longer and longer life expectancy will result in an increase in restaurants and hotels expenditure, and people will strive for its optimal use.

This analysis uses household level data, allowing for both a research of convergence across countries and within countries, specifically looking at economic and socio-demographic groups that share similar budgets and lifestyles. 


\section{LITERATURE}

Alegre, J., Mateo, S., \& Pou, L. (2010). An analysis of households' appraisal of their budget constraints for potential participation in tourism. Tourism Management, 31(1), 45-56.

Angulo, A.M., Gil, J. M., \& Mur, J. (2007). Spanish demand for food away from home: analysis of panel data. Journal of Agricultural Economics, 58(2), 289-307.

Badora, B. (2015). Wyjazdy wypoczynkowe Polaków w 2014 roku i plany na rok 2015. Komunikat $z$ badań [Poles holiday trips in 2014 and plans for 2015. The communication from the study]. Warszawa, Poland: CBOS. Retrieved from http://www.cbos.pl/ SPISKOM.POL/2015/K_016_15.PDF

Bai, J., Zhang, C., Qiao, F., \& Wahl, T. (2012). Disaggregating household expenditures on food away from home in Beijing by type of food facility and type of meal. China Agricultural Economic Review, 4(1), 18-35.

Bąk, I. (2012). Turystyka w obliczu starzejącego się społeczeństwa [Tourism in the face of an aging population]. Prace Naukowe Uniwersytetu Ekonomicznego we Wrocławiu, 258, 13-23.

Bernini, C., \& Cracolici, M. F. (2015). Demographic change, tourism expenditure and life cycle behavior. Tourism Management, 47, 191-205.

Bozoglu, M., Bilgic, A., Yen, S. T., \& Huang, C. L. (2013). Household food expenditure at home and away from home in Turkey. In Selected paper prepared for presentation at the Agricultural and Applied Economics Association (AAEA) and CAES joint Annual meeting. Washington, DC.

Bylok, F. (2013). Strategie zachowań konsumpcyjnych seniorów na rynku dóbr i usług konsumpcyjnych [Strategy of consumer behavior of the elderly on the market of consumer foods and services]. Problemy Zarzadzania, 11(1(40), 123-142.

Chang, H. H., \& Yen, S. T. (2010). Off-farm employment and food expenditures at home and away from home. European Review of Agricultural Economics, 37(4), 523-551.

Czapiński J., \& Panek T. (Eds.). (2014). Diagnoza Społeczna 2013. Warunki i jakość życia Polaków [Social Diagnosis 2000-2013 Objective and Subjective Quality of Life in Poland]. Warszawa, Poland: Rada Monitoringu Społecznego.

Erbe Healy, A. (2014). Convergence or difference? Western European household food expenditure. British Food Journal, 116(5), 792-804.

Eugenio-Martin, J. L., \& Campos-Soria, J. A. (2011). Income and the substitution pattern between domestic and international tourism demand. Applied Economics, 43(20), 2519-2531.

Fish, M., \& Waggle, D. (1996). Current income versus total expenditure measures in regression models of vacation and pleasure travel. Journal of Travel Research, 35(2), 70-74.
Gutkowska, K., Laskowski, W., \& Ozimek, I. (2012). Konsumpcja żywności $w$ polskich gospodarstwach domowych-kryteria zróżnicowania [Food consumption in Polish households-criteria of differentiation]. Warszawa, Poland: Wydawnictwo SGGW.

Jensen, H. H., \& Yen, S. T. (1996). Food expenditures away from home by type of meal. Canadian Journal of Agricultural Economics, 44(1), 67-80.

Kleinbaum, D., Kupper, L., Nizam, A., \& Rosenberg, E. (2013). Applied regression analysis and other multivariable methods. Cengage Learning. In Draper, N. R., \& Smith, H. (Eds.), Applied regression analysis. New York, Chichester, Weinheim, Brisbane, Singapore, Toronto: John Wiley \& Sons Inc.

Kludacz M., \& Piekut M. (2014). European Household Expenditure on Leisure Time Activities. Folia Turistica, 4, 451-458.

Kowalczuk, I. (2013). Specyfika zachowań turystów na rynku usług gastronomicznych [Specificity of Tourists Behaviour in the Market for Catering Services]. Problemy Turystyki i Rekreacji, 3, 63-76.

Laskowski, W. (2014). Dochodowa elastyczność wydatków polskich gospodarstw domowych i jej uwarunkowania. [Income elasticity of Polish household expenditure and its determinant factors]. Zeszyty Naukowe Szkoły Głównej Gospodarstwa Wiejskiego $w$ Warszawie. Problemy Rolnictwa Światowego, 14(1), 63-74.

Lawson, R. (1975). Patterns of tourist expenditure and types of vacation across the family life cycle. Journal of Travel Research, 29.

Liu, M., Kasteridis, P., \& Yen, S. T. (2013). Breakfast, lunch, and dinner expenditures away from home in the United States. Food Policy, in press.

Mancino, L., Todd, J., \& Lin, B. H. (2009). Separating what we eat from where: measuring the effect of food away from home on diet quality. Food Policy, 34(6), 557562.

Migdał-Najman, K., Szreder, M. (2013). Nowe trendy demograficzne a zmiany $\mathrm{w}$ konsumpcji w Polsce [New demographic trends affecting consumption patterns in Poland]. Marketing i Rynek, 20(11), 2-8.

Mihalopoulos, V. G., Demoussis, M. P. (2001). Greek household consumption of food away from home: a microeconometric approach. European Review of Agricultural Economics, 28(4), 421-432.

Montini, A. (2001). Food away from home and households expenditures in Italy. The food consumer in the early 21st century. April 19-20, Zaragoza, Spain.

Mutlu, S., \& Gracia, A. (2006). Spanish food expenditure away from home (FAFH): by type of meal. Applied Economics, 38(9), 1037-1047.

Nicolau J. L., \& Más F. (2005). Stochastic modeling: a three-stage tourist choice process. Annals of Tourism Research, 32(1), 49-69.

Olejniczak, T. (2015). Przemiany segmentu konsumentów seniorów w Polsce [Transformations in the Segment of Senior Consumers in Poland]. Marketing i Rynek, 2(CD), 196-210. 
Piekut M., \& Gutkowska K. (2015). Uwarunkowania poziomu wydatków na turystykę i rekreację oraz usługi gastronomiczne i zakwaterowania w wiejskich gospodarstwach domowych [Determinants of the level of expenditure on tourism, recreation, catering and accommodation in rural households]. Marketing i Rynek, 8(CD), 527-539.

Piekut, M. (2013). Wydatki na zagospodarowywanie czasu wolnego w gospodarstwach domowych [Expenditure on leisure in households]. Ekonomia i Zarzadzanie, 5(3), 64-81.

Pingali, P. (2006). Westernization of Asian diets and the transformation of food systems: Implications for research and policy. Food Policy, 32, 281-298.

Rapoport, R., \& Rapoport, R. N. (1991). Leisure and the family life cycle. London, Great Britain: Routledge and Kegan Paul.

Rout, H. S. (2010). Gender and Household Health Expenditure in Odisha. India Journal of Health Management, 12(4), 445-460.

Sawińska, A. (2014). Seniorzy i preseniorzy jako perspektywiczny podmiot rynku turystycznego i rekreacyjnego [Seniors and pre-seniors as a prospective segment of the tourism and recreation market]. Rozprawy Naukowe Akademii Wychowania Fizycznego we Wrocławiu, 46, 171-177.

Siwuel, K., \& Song Hyun, J. (2010). A Panel Data Analysis of the Determinants of Health Care Expenditures among Older Single-person Households. Journal of Consumer Studies, 21(4), 193-218.

Śniadek, J. (2007). Konsumpcja turystyczna polskich seniorów na tle globalnych tendencji w turystyce [Tourism consumption of polish seniors in the light of global tendencies in tourism]. Gerontologia Polska, 15(1-2), 21-30.

Turystyczne podróże Polaków. Rok 2012: wstępne oszacowania; lata 2013-2017: prognoza [Tourist trips to the Poles. Year 2012 initial estimate; for 2013-2017: forecast]. Retrieved from http://www.intur.com.pl/ images/wykresy/high/podrozepolakow.htm

Wątroba, J. (2004). Analiza wariancji. Materiały kursowe [Analysis of variance. Course materials]. Kraków, Poland: StatSoft.

Wątroba, J. (2008). Modelowanie współzależności zjawisk $w$ STATISTICA. Materiaty kursowe [Modeling the interdependence of phenomena in STATISTICA. Course materials]. Kraków, Poland: StatSoft.

Zalega, T. (2013). Alternatywne trendy konsumenckie w miejskich gospodarstwach domowych w Polsce w okresie kryzysu [Alternative consumption trends in Polish urban households in the period of crisis]. Studia i Materiały/Wydział Zarzadzania. Uniwersytet Warszawski, 16, 56-78. 